\title{
Effect of folic acid on animal models, cell cultures, and human oral clefts: a literature review
}

\author{
Zita C. Bendahan 1* (1), Lina M. Escobar', Jaime E. Castellanos² and María C. González-Carrera
}

\begin{abstract}
Background: Folate is a naturally occurring, water-soluble B vitamin. The synthetic form of this compound is folic acid (FA), the deficiency of which is linked to neural tube disorders (NTD), which can be prevented by consuming it before, or during the early months of, pregnancy. However, the effect of FA on oral cleft formation remains controversial. The aim of the present study was to review the evidence concerning the effect of FA on the formation of cleft lip and palate (CLP) in both animals and humans, as well as its impact on different cell types. A search was conducted on various databases, including MEDLINE, EMBASE, and Central, for articles published until January 2020.
\end{abstract}

Main body: Current systematic reviews indicate that FA, alone or in combination with other vitamins, prevents NTD; however, there is no consensus on whether its consumption can prevent CLP formation. Conversely, the protective effect of FA on palatal cleft (CP) induction has been inferred from animal models; additionally, in vitro studies enumerate a cell-type and dose-dependent effect of FA on cell viability, proliferation, and differentiation, hence bolstering evidence from epidemiological studies.

Conclusions: Meta-analysis, animal models, and in vitro studies demonstrated the protective effect of FA against isolated CP; however, the heterogeneity of treatment protocols, doses, and FA administration method, as well as the different cell types used in in vitro studies, does not conclusively establish whether FA prevents CLP formation.

Keywords: Folic acid, Vitamin B complex, Cleft palate, Cleft lip, Craniofacial abnormalities, Cell proliferation

\section{Background}

Folate is a water-soluble sub-type of vitamin B, present in legumes and vegetables. It is an essential nutrient that cannot be synthesized by humans and therefore must be incorporated through the diet. Folic acid (FA) is the synthetically manufactured form of folate. It is incorporated into supplements and into fortified foods such as cold cereals, bakery products such as cookies and bread, and pastas. Folates are a group of compounds with a structure and biological properties similar to those of FA; they are involved in fundamental

\footnotetext{
* Correspondence: zbendahana@unbosque.edu.co

'UMIMC - Unidad de Manejo Integral de Malformaciones Craneofaciales. Facultad de Odontología, Universidad El Bosque, Av. Cra. 9 No. 131A-02, Bogotá 110121, Colombia

Full list of author information is available at the end of the article
}

processes such as protein and deoxyribonucleic acid (DNA) synthesis [1].

The consumption of multivitamin or FA supplements, before pregnancy and during its early months, aids in preventing neural tube disorders (NTD). Although the exact mechanism by which FA facilitates the closure of the neural tube is not entirely known, it is estimated that up to $70 \%$ of the NTD can be prevented by supplements containing FA [1].

Systematic reviews based on clinical studies have elucidated a protective effect of FA on cleft lip and palate (CLP) formation [2-4] which is the most common congenital craniofacial malformation and the fourth most prevalent congenital anomaly [5]. However, other studies consider the use of multivitamins, but not isolated FA, as the primary factor responsible for preventing the

\section{Springer Open}

(c) The Author(s). 2020 Open Access This article is licensed under a Creative Commons Attribution 4.0 International License, which permits use, sharing, adaptation, distribution and reproduction in any medium or format, as long as you give appropriate credit to the original author(s) and the source, provide a link to the Creative Commons licence, and indicate if changes were made. The images or other third party material in this article are included in the article's Creative Commons licence, unless indicated otherwise in a credit line to the material. If material is not included in the article's Creative Commons licence and your intended use is not permitted by statutory regulation or exceeds the permitted use, you will need to obtain permission directly from the copyright holder. To view a copy of this licence, visit http://creativecommons.org/licenses/by/4.0/. 
formation of CLP [6]; hence, there is currently no substantive consensus on this. Animal study models and certain in vitro studies have also pointed to a protective effect exerted by FA against the cleft palate (CP) [7-9].

CLP occurs due to the lack of the fusion between palatal processes, the maxillary process, and the middle nasal process [10]. Its etiopathology is complex, with three possible groups of associated etiological factors described: environmental, teratogenic, and genetic. At present, the interaction between various epigenetic factors and its influence on the expression of different genes is considered the main etiological factor [11].

The aim of the present review was to assess the evidence regarding the effect of FA on the formation of CLP in both animals and humans, as well as its influence on different cell types.

\section{Methods}

An electronic and manual search of published articles up to January 2020 was performed in the MEDLINE, EMBASE, and Central databases, employing the following search strategy: "folic acid AND cleft lip AND cleft palate AND in vivo studies AND in vitro studies." Articles were selected according to title and abstract information. A full-text evaluation of the selected articles was conducted; relevant information in alignment with the study objective was included in the present review. The obtained results are shown in tables divided into three thematic fields: effect of FA on CLP in humans, effect of FA and orofacial clefts in animals, and FA and its effect on cell cultures.

\section{Effect of folic acid on CLP formation in humans}

Multivitamin or folate supplements taken prior to/during the first 2 months of pregnancy helps to prevent NTD. Wilcox et al. found that the consumption of FA supplements early during pregnancy $(400 \mu \mathrm{g} /$ day $)$ was associated with a one-third reduction in the risk of suffering isolated cleft lip (CL) with/without CP. They also determined that, regardless of supplements, diets rich in fruits, vegetables, and other high-folate foods alleviated the risk. The lowest incidence of $\mathrm{CL}$ was found among women who consumed folate-rich diets and took FA and multivitamin supplements. However, FA did not provide any protection against isolated $\mathrm{CP}$ in that study [12].

In a case-control study conducted by Shaw et al., it was found that women who took periconceptional multivitamins containing FA manifested $25 \% \pm 50 \%$ reduction in the risk of giving birth to children with orofacial clefts [13]. Tolarova and Harris, in a prospective intervention study, found that the consumption of $10 \mathrm{mg}$ of FA daily decreased the recurrence of $\mathrm{CP}$ by $65.4 \%$ in families with a firstdegree relative with a CLP and by $82.6 \%$ in families with a previous child with a unilateral cleft. However, no risk reduction was observed in families with a history of a child with a bilateral cleft [14]. Conversely, Czeizel et al. concluded that consuming FA supplements during the critical period (8-14 gestational weeks) of the lip and palate formation can prevent isolated clefts in these structures, but not CLP, following the intake of a dose lower than $1 \mathrm{mg}$ of FA [15]. Prior studies have reported the incidence of oral clefts in the offspring of women who ingested folate antagonists during pregnancy, such as methotrexate, aminopterin (4pteroylglutamic acid), and anticonvulsants $[13,16]$.

Although the protective effect of folate against CL and CLP is recognized, the mechanism due to which certain people possess intrinsically low levels of folate, presumably predisposing their offspring to NTD and other possible congenital pathologies, remains a contentious subject. Certain studies focused on folate pathway enzymes, such as 5 , 10-methylenetetrahydrofolate reductase (MTHFR), which converts 5,10-methylenetetrahydrofolate to 5methyltetrahydrofolate. These studies demonstrated the association between NTD and the MTHFR C/T mutation (C677T), which induces an alanine to valine substitution in the enzyme. The C677T variant produces a thermolabile enzyme with a reduced activity related to elevated plasma homocysteine (HCY) levels and decreased plasma folate. The authors proposed that homozygosity for the $\mathrm{T}$ or $\mathrm{C}$ allele of the C677T polymorphism in women is an essential susceptibility factor for the development of CLP $[17,18]$.

In the meta-analysis conducted by Goh et al., it was reported that the use of FA-fortified multivitamins by women before conception and during the first trimester of pregnancy is associated with a reduced incidence of several malformations such as NTD, cardiovascular abnormalities, oral clefts, urinary tract abnormalities, congenital hydrocephalus, and limb defects. However, randomized trials are necessary to determine which specific vitamins produce these protective effects $[17,19]$. Wilcox et al. found that the consumption of $400 \mu \mathrm{g} /$ day of FA supplements early during pregnancy results in a one-third reduction in the risk of isolated CL with/without $\mathrm{CP}$. The consumption of FA-rich supplements and diet correlated with the lowest incidence of CL. However, no protection against isolated $\mathrm{CP}$ was observed in that study [12].

Although the abovementioned studies underscore the protective effects of supplements containing FA over the risks of orofacial clefts, especially for CLP, they are impeded by data and design limitations. This is particularly because they lack treatment randomization and control groups, as well as the use of interventions that combine FA with other supplements, thus obscuring the effects produced by FA-only use. The non-random assignment introduces self-selection biases in the treatment, which could potentially confound the results obtained from the study and introduce differences between the treated and untreated groups, related to the effect of the treatment. 
Most previous intervention studies also employed a small sample size and were marked by statistical power limitations.

Other studies do not seem to support the protective effect of preconception FA against orofacial clefts, either in the form of tablets or fortified cereal grains [20]. Additionally, a randomized controlled clinical trial that evaluated FA supplements found no evidence of a protective effect in cases of CL, with/without CP, associated with the consumption of vitamin supplement $s[21]$. Hayes et al., in a case-control study, determined that FA supplements do not impact the risk of oral fissures. Their results are attributed to biological mechanisms related to the formation of the lip and palate. During neural tube closure, neural crest cells migrate from the ectoderm along the lateral margins of the neural plate. These cells experience both caudal and cephalic extensive migration. Development of the face and palate takes place over a period longer than that for neural tube development; furthermore, other physical and developmental factors are involved. Therefore, the role of neural crest cells is only one of a multitude of factors responsible for the development of oral tissues. Even though the neural crest is related to NTD and oral clefts, specific cell types, migratory mechanisms, and differentiation pathways may exhibit different susceptibilities to FA. That study did not demonstrate a protective association between the use of these vitamin supplements during the periconceptional period and the risk of occurrence of oral clefts. However, its findings do not downplay the importance of current recommendations that women of childbearing age should consume a daily supplement of FA, since its protective effect against NTD has been consistently demonstrated [22].

According to previous studies, the administration of FA supplements during the periconceptional period is well documented, resulting in a substantial reduction in the occurrence of NTD. However, whether the specific use of FA modifies the risk of other congenital anomalies, such as CLP, is inconclusive.

The available scientific evidence has been analyzed via five systematic reviews conducted between 2000 and 2019. One of these reviews concluded that there is no firm evidence of an association between the presence of oral clefts and FA-only intake; however, the use of multivitamins early in pregnancy can protect against the formation of oral clefts, specifically CLP [6]. De-Regil et al. concluded in a review that FA, alone or in combination with vitamins and minerals, prevents NTD but does not produce an apparent effect on other congenital disabilities [23]. In contrast, the most recent reviews of Blanco et al. [2], Millacura et al. [3], and Jahanbin et al. [4] indicate that FA exerts a beneficial effect on the prevention of non-syndromic CLP (Table 1).

\section{Folic acid and orofacial cleft formation in animals}

The animal model studies analyzed demonstrated the protective effect of FA against CP [7, 8, 24-28] (Table 2). The experimental design utilized varies among studies: in two of the studies, FA supplementation was enabled via feeding of female mice prior to mating [7, 29]. In certain other studies, FA was administered through injections, either intraperitoneally [8], subcutaneously during pregnancy [24], or intravenously [30]. In a few more studies, cultured ex vivo mouse embryos were treated with FA and retinoic acid $[25,26]$.

The FA doses employed ranged from a minimum dose of $0.09 \mu \mathrm{M} / \mathrm{kg}$ of the weight in FA-deficient diets [7] to $100 \mu \mathrm{M} / \mathrm{kg}$ of the weight [30]. Several prior studies analyzed the effect of FA in comparison with the effects generated by other substances: (a) procarbazine, which retards fetal development and delays ossification of the fetal rat skeleton, as evidenced by fetal weight reduction, extremity malformations, and CP development [24]; (b) succinyl sulfathiazole, an antibiotic that diminishes the gut microflora that synthesizes FA and results in exencephaly, developmental delay, and an $80 \%$ open secondary palate [7]; (c) all-trans retinoic acid (ATRA) as a teratogenic inducer of $\mathrm{CP}[8,25]$; and (d) methionine (Met) because of its apparent positive effect in neural tube closure [8] (Table 2).

FA reduces the incidence of CP between $69.7 \%$ and $100 \%$ in comparison with the number of cases produced by procarbazine [24], succinyl sulfathiazole [7], and ATRA $[8,25]$, thus illustrating the beneficial effects of FA. Additionally, concomitant therapy with FA and Met completely eliminated the prevalence of ATRA-induced CP [8]. FA treatment prior to 13-cis-retinoic acid application in rat embryos significantly alleviated cellular damage in the midfacial process, thus revealing the beneficial effects produced by FA on this tissue [26].

\section{Folic acid and its effect on cell cultures}

It has been established that FA is necessary for cell division, specifically under conditions in which cells undergo rapid proliferation; furthermore, it contributes to the methylation status of essential cell molecules such as DNA, ribonucleic acid (RNA), and proteins [31]. Certain cell types are particularly sensitive to folate, and its deficiency results in evident changes. Specifically, embryonic cells of the neural crest demonstrate an elevated degree of expression of folate receptors, thus indicating a heightened demand for it [32, 33].

Seven studies have analyzed the effect of a wide range of FA concentrations on bone tissue formation in vitro in different cell types: bone marrow mesenchymal cells [9], mouse palate [34], cells of the mouse embryonic neural crest [33], osteoblasts [35], osteoclasts [36], human 


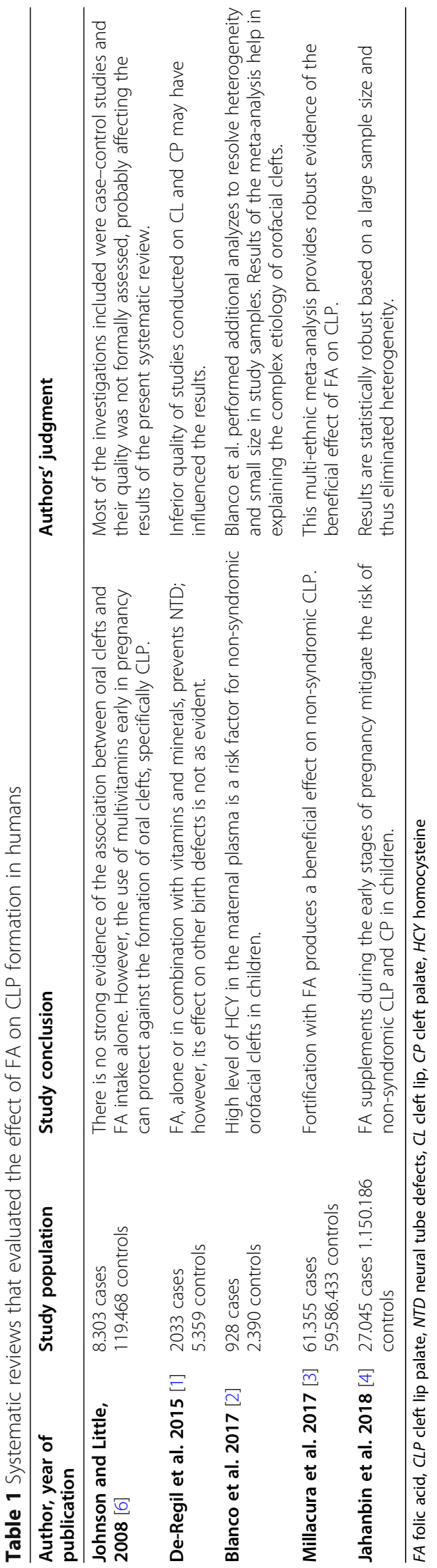




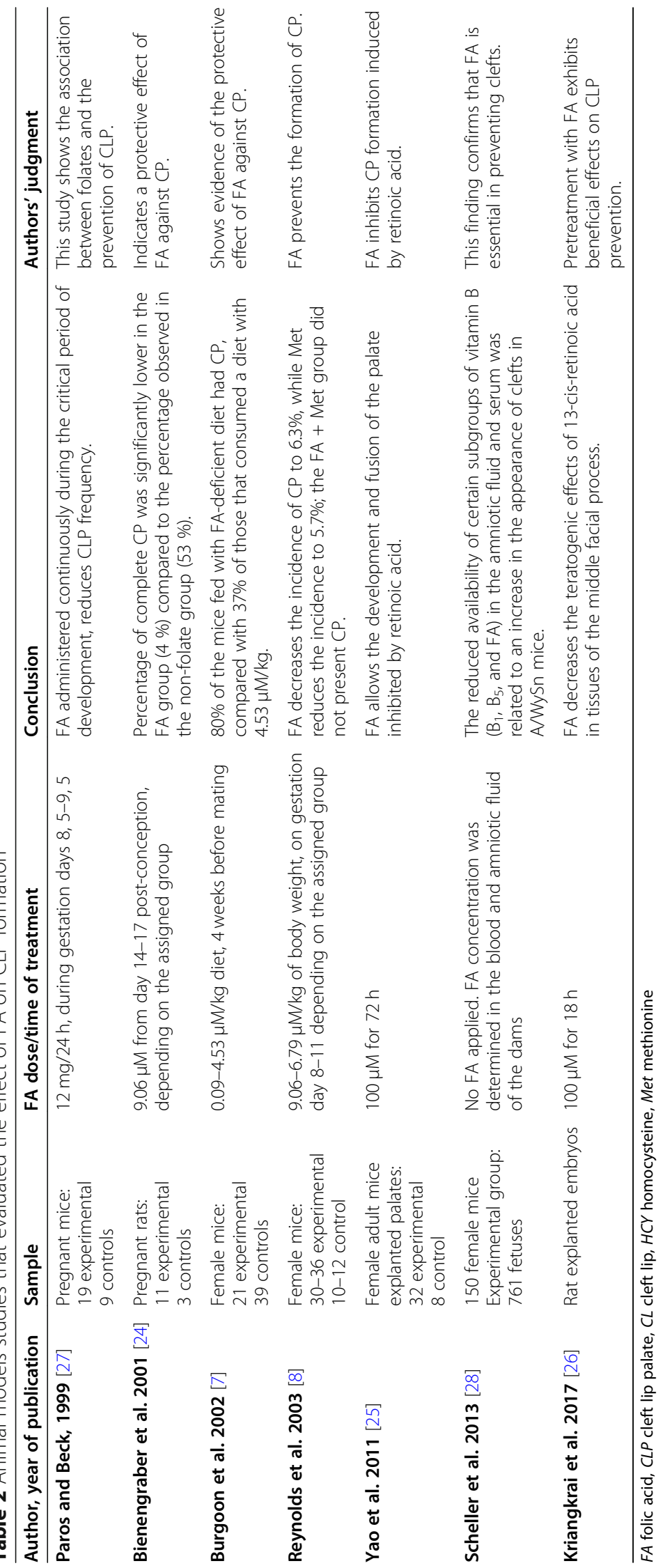




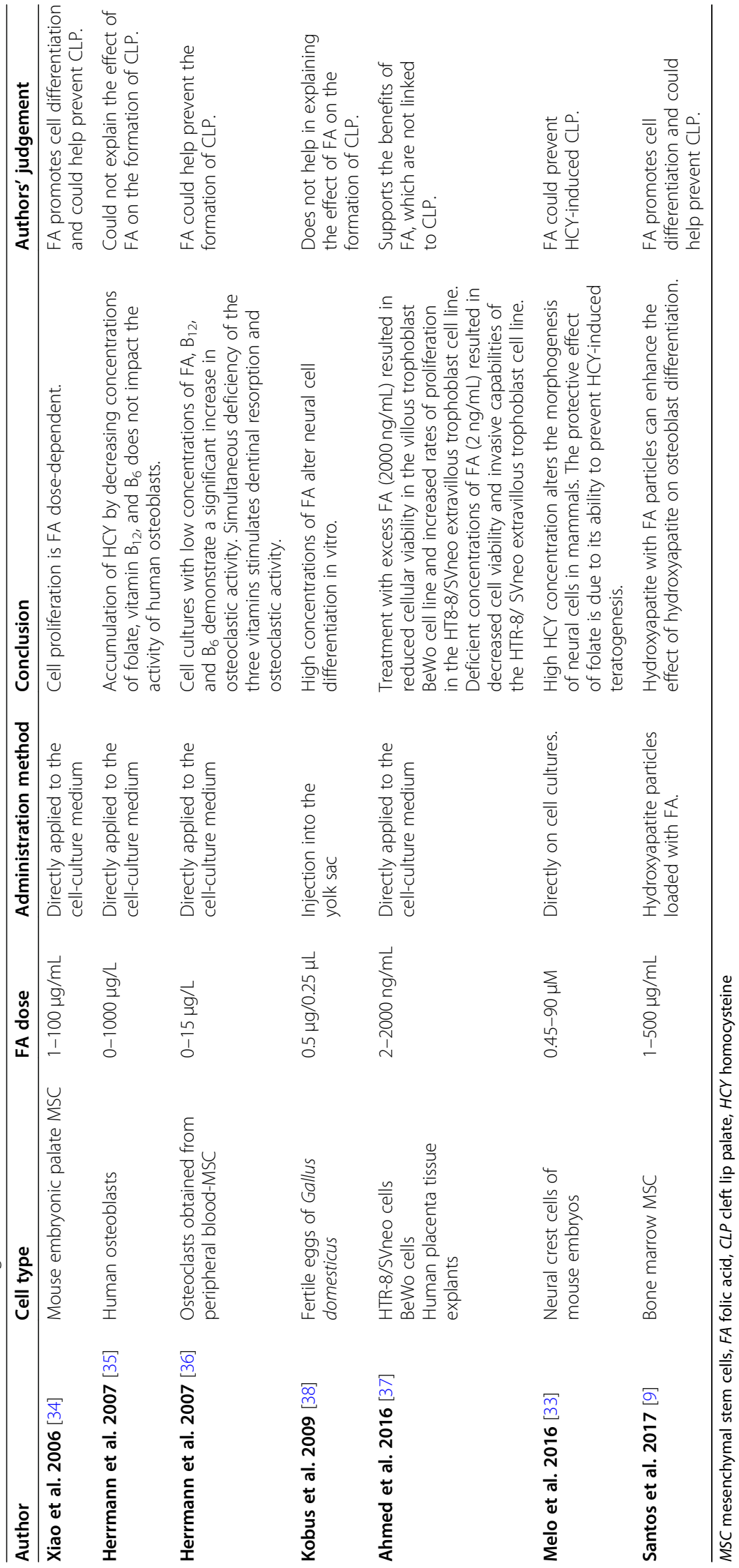


placenta cell lines [37], and directly on chicken embryos [38] (Table 3).

Most studies supplement vitamins in cell cultures through the culture medium; however, Santos et al. exposed cell cultures to hydroxyapatite nanoparticles loaded with FA [9]. In contrast, Kobus et al. injected substances into the yolk sac of chicken embryos [38].

The results of five of the analyzed studies reinforced the effect of FA on the proliferation, viability, and differentiation of various cell types $[9,33,34,36,37]$. However, Herrmann et al. found that $\mathrm{HCY}$ accumulation caused by low folate concentrations does not affect the activity of primary human osteoblasts [35]. Additionally, Melo et al. and Kobus et al. concluded that high concentrations of FA alter neural cell differentiation in vitro, which explains the mechanism of action of FA on NTD but does not explain the effect of FA on the formation of CLP [33, 38] (Table 3).

FA enhanced the proliferation of murine embryonic palatal mesenchymal cells restricted by the MTHFR gene silencing [34]. On the contrary, low FA concentrations augment human osteoclast activity. Also, combined deficiency of FA and vitamins $\mathrm{B}_{12}$ and $\mathrm{B}_{6}$ and increased concentrations of HCY stimulate dentine resorption, tartrateresistant acid phosphatase, and cathepsin activity of cultured osteoclasts causing acidification and proteolytic digestion, leading to bone matrix resorption [36]. Differences observed between studies related to HCYinduced teratogenic effects are supported by the idea that its effects are time and cell type-dependent [33], and FA effect depends also on the applied dose and cell type.

There are multiple potential mechanisms of action of FA. According to Melo et al., the protective effect of FA could be due to its ability to prevent HCY-induced teratogenesis [33]; Santos et al. found that FA serves as a methyl donor to a variety of target molecules: for instance, the methylation of $\mathrm{HCY}$ to Met, the latter being transformed to S-adenosylcysteine and is the first methyl donor. Consequently, FA maintains the cellular methylation status [9], necessary for DNA, RNA, protein, and neurotransmitter synthesis [19]. From a clinical point of view, Ahmed et al. reported that FA deficiency may directly affect trophoblast invasion, possibly resulting in placental dysfunction and compromising fetal development [37]. Taken together, in vitro experiments support evidence from epidemiological studies reporting that FA supplements mitigate CLP risk $[9,33,34,36,37]$.

\section{Conclusions}

Epidemiological studies have demonstrated that periconceptional FA supplements lead to a substantial reduction in the occurrence of NTD. The meta-analysis conducted provided robust evidence of the beneficial effect of FA on CLP; however, the high degree of heterogeneity between studies compels interpreting the results with caution. Animal models studies also demonstrated the protective effect of FA against CP; additionally, in vitro studies indicate a cell-type and dose-dependent effect of FA on cell viability, proliferation, and differentiation. They also lend support to evidence derived from epidemiological studies. Nevertheless, the heterogeneity of treatment protocols, with respect to dose and FA administration method, as well as the diversity of cell types used in in vitro studies, does not establish with certainty whether FA prevents CLP formation. Taken together, the present review supports the promotion of prenatal and early-pregnancy FA supplementation, in addition to a FA-fortified diet, to help prevent CLP formation. It also recognizes the necessity of in vitro studies that analyze FA pathways to understand its mechanisms of action and its effect on CL, CP, and CLP formation.

\section{Abbreviations \\ ATRA: All-transretinoic acid; CL: Cleft lip; CLP: Cleft lip and palate; DNA: Deoxyribonucleic acid; FA: Folic acid; HCY: Homocysteine; MSC: Mesenchymal stem cells; Met: Methionine; MTHF \\ R: Methylenetetrahydrofolate reductase; NTD: Neural tube disorders; CP: Palatal cleft or cleft palate; RNA: Ribonucleic acid \\ Acknowledgements \\ Not applicable.}

\section{Authors' contributions}

ZB contributed to the concepts, design, definition of the intellectual content, literature search, data acquisition, manuscript preparation, manuscript editing, and guarantor of the study. LE contributed to the concepts, design, definition of the intellectual content, literature search, data acquisition, manuscript preparation, manuscript editing, and manuscript review. JC contributed to the concepts, design, definition of the intellectual content, manuscript preparation, and manuscript review. MGC contributed to the concepts, design, definition of the intellectual content, manuscript preparation, and manuscript review. The authors have read and approved the manuscript.

\section{Funding}

We declare no sources of funding to be acknowledged.

Availability of data and materials

Not applicable.

Ethics approval and consent to participate

Not applicable.

Consent for publication

Not applicable.

\section{Competing interests}

The authors declare that they have no competing interests.

\section{Author details}

${ }^{1}$ UMIMC - Unidad de Manejo Integral de Malformaciones Craneofaciales. Facultad de Odontología, Universidad El Bosque, Av. Cra. 9 No. 131A-02, Bogotá 110121, Colombia. ${ }^{2}$ Grupo de Virología, Universidad El Bosque, Av. Cra. 9 No. 131A-02, Bogotá 110121, Colombia.

Received: 10 June 2020 Accepted: 3 November 2020

Published online: 26 November 2020

\section{References}

1. De-Regil LM, Fernández-Gaxiola AC, Dowswell T, Peña-Rosas JP (2010) Effects and safety of periconceptional folate supplementation for 
preventing birth defects. Cochrane Database Syst Rev 10:CD007950. https:// doi.org/10.1002/14651858.CD007950.pub2

2. Blanco R, Colombo A, Pardo R, Suazo J (2016) Maternal biomarkers of methylation status and non-syndromic orofacial cleft risk: a meta-analysis. Int J Oral Maxillofac Surg 45:1323-1332. https://doi.org/10.1016/j.jom.2016. 06.011

3. Millacura N, Pardo R, Cifuentes L, Suazo J (2017) Effects of folic acid fortification on orofacial clefts prevalence: a meta-analysis. Public Health Nutr 20:2260-2268. https://doi.org/10.1017/S1368980017000878

4. Jahanbin A, Shadkam E, Miri HH, Shirazi AS, Abtahi M (2018) Maternal folic acid supplementation and the risk of oral clefts in offspring. J Craniofac Surg 29:e534-e541. https://doi.org/10.1097/SCS.0000000000004488

5. American Cleft Palate-Craniofacial Association. Parameters for evaluation and treatment of patients with cleft lip/palate or other craniofacial anomalies [Internet]. Chapel Hill: American Cleft Palate-Craniofacial Association; 2009 [citado 15 de enero 2020]. p. 7. Disponible en: http://www.acpa-cpf.org

6. Johnson CY, Little J (2008) Folate intake, markers of folate status and oral clefts: is the evidence converging? Int J Epidemiol 37:1041-1058. https://doi. org/10.1093/ije/dyn098

7. Burgoon JM, Selhub J, Nadeau M, Sadler TW (2002) Investigation of the effects of folate deficiency on embryonic development through the establishment of a folate deficient mouse model. Teratology. 65:219-227. https://doi.org/10.1002/tera.10040

8. Reynolds PR, Schaalje GB, Seegmiller RE (2003) Combination therapy with folic acid and methionine in the prevention of retinoic acid-induced cleft palate in mice. Birth Defects Res A Clin Mol Teratol. 67:168-173. https://doi. org/10.1002/bdra.10036

9. Santos C, Gomes P, Duarte JA, Almeida MM, Costa ME, Fernandes MH (2017 Jan 10) Development of hydroxyapatite nanoparticles loaded with folic acid to induce osteoblastic differentiation. Int J Pharm 516(1-2):185-195. https:// doi.org/10.1016/j.jpharm.2016.11.035

10. Brown NL, Sandy JR (2002) Basic sciences in normal and abnormal palate development. Braz J Oral Sci 1:60-70. https://doi.org/10.20396/bjos.v1i2.8641022

11. Guarnizo S (2017) Caracterización geoespacial de personas con labio y paladar hendido en el territorio colombiano en el periodo 2010 - 2015 [tesis de especialización]. Universidad Nacional de Colombia, Bogotá, 106p

12. Wilcox AJ, Lie RT, Solvoll K, Taylor J, McConnaughey DR, Abyholm F et al (2007) Folic acid supplements and risk of facial clefts: national populationbased case-control study. Br Med J 334:433-434. https://doi.org/10.1136/ bmj.39079.618287.0B

13. Shaw GM, Lammer EJ, Wasserman CR, O'Malley CD, Tolarova MM (1995) Risks of orofacial clefts in children born to women using multivitamins containing folic acid periconceptionally. Lancet. 346:393-396. https://doi. org/10.1016/50140-6736(95)92778-6

14. Tolarova M, Harris J (1995) Reduced recurrence of orofacial clefts after periconceptional supplementation with high-dose folic acid and multivitamins. Teratology. 51:71-78. https://doi.org/10.1002/tera.1420510205

15. Czeizel AE, Tímár L, Sárközi A (1999 Dec) Dose-dependent effect of folic acid on the prevention of orofacial clefts. Pediatrics. 104(6):e66. https://doi. org/10.1542/peds.104.6.e66

16. Hernández-Díaz S, Werler MM, Walker AM, Mitchell AA (2000) Folic acid antagonists during pregnancy and the risk of birth defects. N Engl J Med 343:1608-1614. https://doi.org/10.1056/NEJM200011303432204

17. Martinelli M, Scapoli L, Pezzetti F, Carinci F, Carinci P, Stabellini G, et al. C677T variant form at the MTHFR gene and CL/P: a risk factor for mothers? Am J Med Genet. 2001;98:357-60, doi: 10.1002/1096-8628(20010201)98:4 < 357::aid-ajmg $108>$ 3.0.co;2-f.

18. Van Rooij IA, Vermeij-Keers C, Kluijtmans LA, Ocké MC, Zielhuis GA, Goorhuis-Brouwer SM et al (2003) Does the interaction between maternal folate intake and the methylenetetrahydrofolate reductase polymorphisms affect the risk of cleft lip with or without cleft palate? Am J Epidemiol 157: 583-591. https://doi.org/10.1093/aje/kwg005

19. Goh IY, Bollano E, Einarson TR, Koren G (2006) Prenatal multivitamin supplementation and rates of congenital anomalies: a meta-analysis. Obstet Gynaecol Can 28:680-689. https://doi.org/10.1016/S17012163(16)32227-7

20. Ray JG, Meier C, Vermeulen MJ, Wyatt PR, Cole DE (2003) Association between folic acid food fortification and congenital orofacial clefts. J Pediatr 143:805-807. https://doi.org/10.1067/50022-3476(03)00495-5
21. Czeizel AE, Dudás I (1992) Prevention of the first occurrence of neural-tube defects by periconceptional vitamin supplementation. N Engl J Med 327: 1832-1835. https://doi.org/10.1056/NEJM199212243272602

22. Hayes C, Werler MM, Willett WC, Mitchell AA (1996) Case-control study of periconceptional folic acid supplementation and oral clefts. Am J Epidemiol 143:1229-1234. https://doi.org/10.1093/oxfordjournals.aje.a008710

23. De-Regil LM, Peña-Rosas JP, Fernández-Gaxiola AC, Rayco-Solon P (2015) Effects and safety of periconceptional oral folate supplementation for preventing birth defects. Cochrane Database Syst Rev 14:CD007950. https:// doi.org/10.1002/14651858.CD007950.pub3

24. Bienengräber V, Malek FA, Möritz KU, Fanghänel J, Gundlach KK, Weingärtner J (2001) Is it possible to prevent cleft palate by prenatal administration of folic acid? An experimental study. Cleft Palate Craniofac J 38:393-398. https://doi.org/10.1597/1545-1569_2001_038_0393_iiptpc_2.0. CO_2

25. Yao Z, Chen D, Wang A, Ding $X$, Liu Z, Ling $L$ et al (2011) Folic acid rescue of ATRA-induced cleft palate by restoring the TGF- $\beta$ signal and inhibiting apoptosis. J Oral Pathol Med 40:433-439. https://doi.org/10.1111/j.16000714.2010.00994.x

26. Kriangkrai R, Chareonvit S, Iseki S, Limwongse V (2017) Pretreatment effect of folic acid on 13-cis-RA-induced cellular damage of developing midfacial processes in cultured rat embryos. Open Dent J 11:200-212. https://doi.org/ 10.2174/1874210601711010200

27. Paros A, Beck SL (1999 Dec) Folinic acid reduces cleft lip [CL(P)] in a/WySn mice. Teratology. 60(6):344-347

28. Scheller K, RöckI T, Scheller C, Schubert J (1601) Lower concentrations of Bvitamin subgroups in the serum and amniotic fluid correlate to cleft lip and palate appearance in the offspring of a/WySn mice. J Oral Maxillofac Surg 2013(71):e1-e7. https://doi.org/10.1016/j.joms.2013.02.020

29. Barua S, Chadman KK, Kuizon S, Buenaventura D, Stapley NW, Ruocco F et al (2014) Increasing maternal or post-weaning folic acid alters gene expression and moderately changes behavior in the offspring. PLoS One 9:e101674. https://doi.org/10.1186/s12929-014-0077-z

30. Akpınar A, Karakan NC, Alpan AL, Dogan SSA, Goze F, Poyraz O (2016) Comparative effects of riboflavin, nicotinamide and folic acid on alveolar bone loss: a morphometric and histopathologic study in rats. Srp Arh Celok Lek 144:273-279. https://doi.org/10.2298/sarh1606273a

31. Goh YI, Koren G (2008) Folic acid in pregnancy and fetal outcomes. J Obstet Gynaecol 28:3-13. https://doi.org/10.1080/01443610701814195

32. Obican SG, Finnell RH, Mills JL, Shaw GM, Scialli AR (2010) Folic acid in early pregnancy: a public health success story. FASEB J 24:4167-4174. https://doi. org/10.1096/fj.10-165084

33. Melo FR, Bressan RB, Costa-Silva B, Trentin AG (2016) Effects of folic acid and homocysteine on the morphogenesis of mouse cephalic neural crest cells in vitro. Cell Mol Neurobiol 37:371-376. https:/doi.org/10.1007/s10571-016-0383-y

34. Xiao WL, Wu M, Shi B. Folic acid rivals methylenetetrahydrofolate reductase(MTHFR) gene-silencing effect on MEPM cell proliferation and apoptosis. Mol Cell Biochem. 2006 Nov;292(1-2):145-54. Epub 2006 Jul 11. Erratum in: Mol Cell Biochem. 2007;296(1-2):203-4, doi: https://doi.org/10. 1007/s11010-006-9228-1

35. Herrmann M, Umanskaya N, Wildemann B, Colaianni G, Schmidt J, Widmann T et al (2007 Sep) Accumulation of homocysteine by decreasing concentrations of folate, vitamin B12 and B6 does not influence the activity of human osteoblasts in vitro. Clin Chim Acta 384(1-2):129-134. https://doi. org/10.1016/j.cca.2007.06.016

36. Herrmann M, Schmidt J, Umanskaya N, Colaianni G, Al Marrawi F, Widmann T et al (2007 Oct) Stimulation of osteoclast activity by low B-vitamin concentrations. Bone. 41(4):584-591. https://doi.org/10.1111/j.1582-4934. 2008.00104.x

37. Ahmed T, Fellus I, Gaudet J, MacFarlane AJ, Fontaine-Bisson B, Bainbridge SA (2016 Jan) Effect of folic acid on human trophoblast health and function in vitro. Placenta. 37:7-15. https://doi.org/10.1016/j.placenta.2015.11.012

38. Kobus K, Nazari EM, Müller YM (2009) Effects of folic acid and homocysteine on spinal cord morphology of the chicken embryo. Histochem Cell Biol 132: 525-532. https://doi.org/10.1007/s00418-009-0630-0

\section{Publisher's Note}

Springer Nature remains neutral with regard to jurisdictional claims in published maps and institutional affiliations. 